\title{
POSTERIOR PARIETAL CORTEX ROLE IN A SENSORIMOTOR TASK PERFORMANCE
}

\author{
Sergio Nader', Sergio Machado ${ }^{1,5}$, Marlo Cunha ${ }^{1,5}$, Cláudio Elidio Portella', \\ Julio Guilherme Silva ${ }^{1,5}$, Bruna Velasques, ${ }^{1,5}$, Victor Hugo Bastos ${ }^{1,5}$, Luis Basile ${ }^{2}$, \\ Mauricio Cagy ${ }^{4}$, Roberto Piedade ${ }^{1}$, Pedro Ribeiro ${ }^{1,3,5}$
}

\begin{abstract}
This study aimed to elucidate electrophysiological and cortical mechanisms involved in anticipatory actions when individuals had to catch balls in free drop; specifically through quantitative electroencephalography ( $q E E G$ ) alpha absolute power changes. The sample was composed for 23 health subjects, both sexes, with ages varying between 25 and 40 years, absence of mental and physical illness, right handed and don't make use of any psychoactive or psychotropic substance at the time of the study. The experiment consisted of a task of catching balls in free drop. The three-way ANOVA analysis demonstrated an interaction between moment and position factors in left parietal posterior cortex (PPC) $(p=0.001)$. Through the experimental task employed, this area demonstrated a differentiated activity involving expectation, planning and preparedness in the ball's drop task.
\end{abstract}

KEY WORDS: absolute power, catch, qEEG, sensorimotor integration.

\section{Papel do córtex parietal posterior na realização de uma tarefa sensório-motora}

Resumo - $O$ estudo tentou elucidar mecanismos eletrofisiológicos e corticais envolvidos em ações antecipatórias quando os sujeitos testados tiveram que apreender bolas em queda livre; especificamente através de mudanças na potência absoluta na banda alfa da eletrencefalografia quantitativa (EEGq). A amostra foi composta por 23 sujeitos sadios, ambos os sexos, idade entre variando entre 25 e 40 anos, sem comprometimento físico e mental, destros, e não fazer uso de nenhuma substância psicoativa ou psicotrópicos até o momento do estudo. $\mathrm{O}$ experimento consistiu de uma tarefa de apreensão de bolas em queda livre. A análise three-way ANOVA demonstrou uma interação entre os fatores momento e posição no córtex parietal posterior (CPP) esquerdo $(p=0,001)$. Através da tarefa experimental empregada, esta área demonstrou uma atividade diferenciada envolvendo expectativa, planejamento e prontidão na tarefa de queda de bolas.

PALAVRAS-CHAVE: potência absoluta, apreender, EEGq, integração sensório-motora.

The posterior parietal cortex (PPC) plays a crucial role in relation to motor planning based on sensory information. Human functional magnetic resonance imaging (fMRI) experiments and electrophysiological recordings in nonhuman primates have shown that the PPC is neither sensory nor motor purely, but it is an area that encodes cognitive functions related to action ${ }^{1,2}$. The presence of sensory and motor specific representations together with high-level cognitive signals suggests that the PPC plays an important role for decision making related to action ${ }^{2}$.
Such representations are elementary components in the preparation and adjustment of a motor act and they take part in the integration among different and specialized centers in the final movement production ${ }^{3}$. This process occurs through sensorimotor integration, when sensory information is integrated by central nervous system to attend to motor programs.

Catching an object is a complex movement which involves not only programming but also effective motor coordination. Such behavior is related to the activation and

\footnotetext{
'Laboratório de Mapeamento Cerebral e Integração Sensório-Motora, Programa de Pós-Graduação em Psiquiatria e Saúde Mental (PROPSAM), Instituto de Psiquiatria da Universidade do Brasil (IPUB), Universidade Federal do Rio de Janeiro, Brasil (UFRJ); ${ }^{2}$ Divisão de Neurocirurgia Funcional, Instituto de Psiquiatria, Escola de Medicina, Universidade de São Paulo, Brasil (USP); ${ }^{3}$ Departamento de Biociências da Atividade Física, Faculdade de Educação Física e Desportos (EEFD), Universidade Federal do Rio de Janeiro, Brasil (UFRJ); ${ }^{4}$ Departamento de Epidemiologia e Bioestatística, Instituto de Saúde da Comunidade, Universidade Federal Fluminense, Niterói, Brasil (UFF); ${ }^{5}$ Instituto Brasileiro de Biociências Neurais, Rio de Janeiro, Brasil (IBBN). Sergio Machado was supported by CAPES doctoral program grant. Marlo Cunha was supported by CNPq doctoral program grant. Mauricio Cagy was supported by FAPERJ postdoctoral grant.
}

Received 8 February 2008, received in final form 8 April 2008. Accepted 25 April 2008.

Dr. Sergio Eduardo de Carvalho Machado - Rua Professor Sabóia Ribeiro 69 / 104 - 22430-130 Rio de Janeiro RJ - Brasil. E-mail: secm80@yahoo.com.br 
recruitment of cortical regions which take part in the integration process that occurs between the information coming from the environment and the motor task performace ${ }^{4}$. Plastic alterations might occur in brain areas regarding motor reactions (anticipatory movements and motor learning), which might lead to performance and gesture precision improvement ${ }^{5}$. The quantitative electroencephalographic ( $\mathrm{qEEG}$ ) technique is able to detect the brain region activated during the preparation and execution of a certain task and the level of neuronal activity in different brain areas ${ }^{6,7}$. Counting on a high temporal resolution, the QEEG has made the elucidation of cognitive processes and motor learning ${ }^{8}$.

This study aimed to elucidate electrophysiological and cortical mechanisms involved in anticipatory actions when individuals had to catch balls in free-drop, specially through qEEG alpha absolute power changes.

\section{METHOD}

The sample was composed of 23 healthy individuals, both sexes, right handed ${ }^{9}$, with ages varying between 25 and 40 years old. Inclusion criteria were: absence of mental or physical impairments (screened by a previous anamnesis) and not receiving any psychoactive or psychotropic substances. The experiment consisted of a task of catching balls in free drop. The balls were discharged by an electromagnetic system. The interval between the ball's drops was 11 seconds, each ball was a trial and each block was made of 15 trials. The experiment consisted of six blocks, lasting $2 \mathrm{~min}$ and $30 \mathrm{sec}$ each, with $1 \mathrm{~min}$-interval between the blocks. These intervals favored the recovery of the active limb, avoiding muscular fatigue. The qEEG acquisition was collected using the international 10/20 system ${ }^{10}$ during $2 \mathrm{sec}-$ onds before and after the ball's drop. This methodology has already been utilized in other experiment conducted in the Brain Mapping and Sensorimotor Integration Laboratory". It was also done an electromyography (EMG) analysis in the experiment. EMG was used in order to detect and remove possible artifacts related to the ball's fall that could affect the electroencephalographic signal.

\section{EMG}

Electromyographic (EMG) activity of the flexor carpi radialis (FCR), flexor carpi ulnaris (FCU), extensor carpi radialis (ECR) and extensor carpi ulnaris (ECU) was recorded by an EMG device (Lynx-EMG1000), to monitor and assess any voluntary movement during the task. Bipolar electrodes $(2 \mathrm{~mm}$ recording diameter) were attached to the skin. The reference electrode was fixed on the skin overlying the lateral epicondyle near the wrist joint. The skin was cleaned with alcohol prior to electrode attachment. The EMG was amplified ( $\times 1000)$, filtered (10-3000 $\mathrm{Hz}$ ), digitized (10000 samples/s), and recorded synchronously to the EEG onto the computer's hard drive. In each trial, the
EMG signal was rectified and averaged over $500 \mathrm{~ms}$ from the trigger point.

Spatial electrode localization and frequency bands

The electrode pairs P3-PZ and P4-PZ represent the PPC, functionally related to sensorimotor orientation ${ }^{12}$. The alpha band (8-12 Hz) was chosen due to its association with sensory, cognitive and motor mechanisms ${ }^{13,14}$.

\section{Statistical analysis}

A three-way ANOVA and a post hoc test were utilized. The factors moment (pre and post ball's drop), blocks (1 to 6) and position (P3-PZ versus P4-PZ electrode pairs) were compared ( $\mathrm{P} \leq$ 0.05 ). The EEG absolute power values were log-transformed by SPSS software (version 15.0) to approximate a normal distribution.

\section{RESULTS}

Our data demonstrated an interaction between moment and position factors in the left PPC when compared with the homologous region $(p=0.001)$. It was noted a significant decrease in absolute power values in pre ball's drop period ( mean $=3.34 ; \mathrm{sd}=0.077$ ) in relation to post ball's drop period ( $m e a n=3.68$; $s d=0.037$ ) as observed in the Figure.

\section{DISCUSSION}

The current experiment is an attempt to understand cortical/electrophysiological mechanisms regarding anticipatory actions involved in voluntary movements, specially, when subjects had to catch balls in free drop. We observed an interaction between moment (i.e., 2 sec before and $2 \mathrm{sec}$ after the ball's drop) and scalp's position (PPC). It was noted a decrease in power during the pre drop period

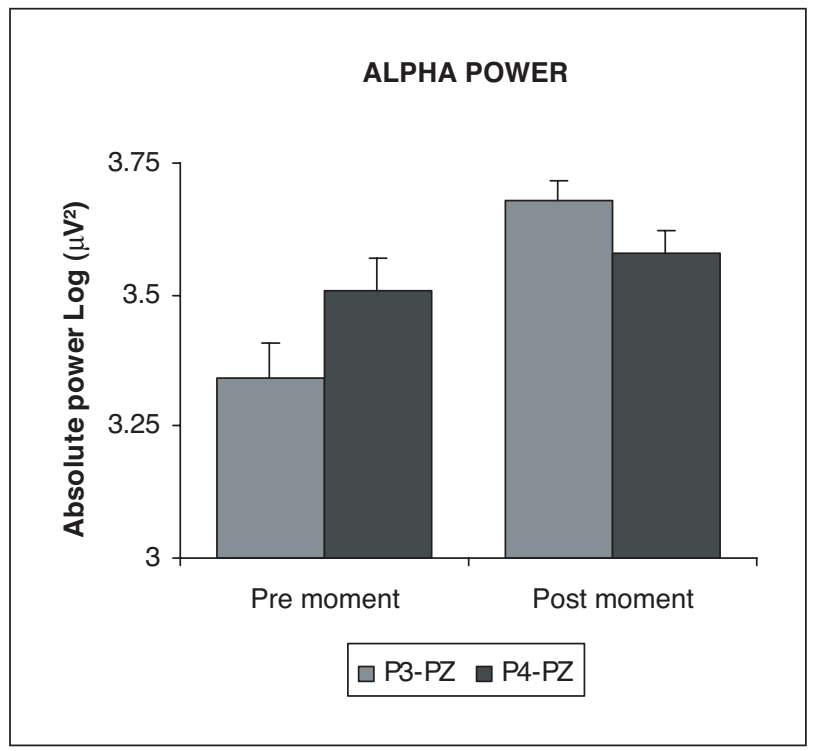

Figure. Interaction between moment and position in alpha absolute power. 
in the left PPC (i.e., P3-PZ electrode pair) when compared with the right PPC (i.e., P4-PZ electrode pair). This behavior indicates an increase in activity in this region during motor planning of the contralateral limb (e.g., considering the inverse relation of alpha band). Previous experiments report that the PPC is responsible for initiation and sensorimotor guidance, limb motor preparation and handling of objects, via visual and propioceptive information to attend to motor planning ${ }^{2,15}$. In relation to ball's drop task, there is a considerable propioceptive and visual demand involved, which justifies the activation of the left PPC ${ }^{16}$. Therefore, in the pre ball's drop period, the data suggest a strong integration between propioceptive information (hand's position) and visual information (spatio-temporal coordination regarding the ball's contact with the hand). These activities regarding to sensory modalities explain the greater activation of the left PPC, specially in pre ball's drop period. The results obtained by Wheaton et al. ${ }^{17}$ support our data. An alpha power decrease in left PPC during movement preparation in healthy subjects was found.

On the other hand, the post ball's drop period revealed an increase in power values in left PPC (i.e., the P3-PZ electrode pair) when compared with right PPC (i.e., the P4-PZ electrode pair). It seems to reflect a decrease in neural activity, suggesting a decreased expectation, alertness and readiness subsequent to the ball's drop. It could be interpreted as a deactivation of the involved cortical area ${ }^{18}$. In this period, due to be a task performed in open circuit, i.e., the movements are fast enough to allow feedback information in real time ${ }^{19}$, which could occurred a decrease in this specific cortical activation. Similarly, the subjects were able to exploit, additionally, the visual information available on the brief period of time in the early ball's drop period (pre ball's drop period). This sensory requirement becomes less active in the post ball's drop period, which concerns the motor implementation or the hand's movement to catch the ball.

Through the experimental task employed, the left PPC showed a differentiated activity involving expectation, planning and preparedness in the ball's drop task. In this phase, the left PPC may provides information about arm's coordination and finger movements when moved to visual targets ${ }^{16}$ and also anticipatory coordination of grip and load forces to maintain grasp stability during object manipulation ${ }^{20}$, which occur before the motor execution as a basis for the movement organization. We recommend new investigations should replicate these findings maybe utilizing new paradigms, different objects and randomization time. Moreover, different population, other than healthy subjects, should also be considered for new experiments, for example, patients suffering from Alzheimer disease and Parkinson disease, in an attempt to observe specific variables such as attention, episodic memory, anticipatory movements, reaction time and motor planning and execution.

ACKNOWLEDGEMENTS - We thank Edson Colona for technical assistance with the experimental apparatus.

\section{REFERENCES}

1. Rushworth MF, Paus T, Sipila PK. Attention systems and the organization of the human parietal cortex. J Neurosci 2001;21:5262-5271.

2. Musallam S, Corneil BD, Greger B, et al. Cognitive control signals for neural prosthetics. Science 2004;305:258-262.

3. Nargeot R. Votage-dependent switching of sensorimotor integration by a lobster central pattern generator. J Neurosci 2003;23:4803-4808.

4. Chapman H, Pierno AC, Cunnington R, et al. The neural basis of selection-for-action. Neurosci Lett 2007;417:171-175.

5. Karni A, Meyer G, Rey-Hipólito C, et al. The acquisition of skilled motor performance: fast and slow experience-driven changes in primary motor cortex. Proc Natl Acad USA 1998;95:861-868.

6. Hung T, Saarela P, Hatfield B. Eletroencephalography and mental states associated with elite performance. J Sport Exerc Psychol 1998;20:35-53.

7. Pfurtscheller G, Lopez da Silva F. Event-related EEG/MEG synchronization and desynchronization: basic principles. Clin Neurophysiol 1999;110:1842-1857.

8. Smith ME, Mcevoy L, Gevins A. Neurophysiological indices of strategy development and skill acquisition. Brain Res Cogn Brain Res 1999;7:389-404.

9. Oldfield R. The assessment and analysis of handedness: the Edinburgh inventory. Neuropsychologia 1971;9:97-113.

10. Jasper H. The ten-twenty electrode system of the international federation. EEG Clin Neurophysiol 1958;10:371-375.

11. Portella CE, Silva JG, Machado S, et al. EEG spectral coherence interand intrahemispheric during catching object fall task. Arq Neuropsiquiatr 2007;65:63-67.

12. Del Percio C, Marzano N, Tilgher S, et al. Pre-stimulus alpha rhythms are correlated with post-stimulus sensorimotor performance in athletes and non-athletes: a high-resolution EEG study. Clin Neurophysiol 2007;118:1711-1720.

13. Bastiaansen MCM, Böcker KBE, Brunia CHM, et al. Event-related desynchronization during anticipatory attention for an upcoming stimulus: a comparative EEG-EMG study. Clin Neurophysiol 2001;112:393-403.

14. Pfurtscheller G, Pichler-Zalaudek K, Neuper C. ERD and ERS in voluntary movement of different limbs. In: Pfurtscheller G, Lopes da Silva FH (Eds). Event-related desynchronization handbook of electroencephalography and clinical neurophysiology, vol. 6. Revised edition, Amsterdam: Elsevier, 1999:245-268.

15. Beurze SM, de Lange FP, Toni I, et al. Integration of target and effector information in the human brain during reach planning. J Neurophysiol 2007;97:188-199.

16. Ramnani N, Toni I, Passingham RE, et al. The cerebellum and parietal cortex play a specific role in coordination: a PET study. Neuroimage 2001;14:899-911.

17. Wheaton LA, Shibasaki H, Hallett M. Temporal activation pattern of parietal and premotor areas related to praxis movements. Clin Neurophysiol 2005;116:1201-1212.

18. Bastiaansen, MCM, Brunia CHM, Böcker KBE. ERD as an index of anticipatory behavior. In: Pfurtscheller G, Lopes da Silva FH (Eds). Eventrelated desynchronization handbook of electroencephalography and clinical neurophysiology, vol. 6. Revised edition, Amsterdam: Elsevier, 1999:203-217.

19. Bagesteiro LB, Sainburg RL. Nondominant arm advantages in load compensation during rapid elbow joint movements. J Neurophysiol 2003;90:1503-1513.

20. Ehrsson HH, Fagergren A, Johansson RS, et al. Evidence for the involvement of the posterior parietal cortex in coordination of fingertip forces for grasp stability in manipulation. J Neurophysiol 2003;90:2978-2986. 